\title{
Strategi Kepala Madrasah..dalam Membangun Budaya Religius Peserta Didik
}

\author{
Ahmad Tajudin, Andika Aprilianto \\ ${ }^{1}$ Fakultas Tarbiyah Institut Pesantren Kh. Abdul Chalim Pacet Mojokerto \\ e-mail: Saudara.ahmad03@gmail.com
}

Submitted: 05-08-2020 Revised : 15-08-2020 Accepted: 05-09-2020

\begin{abstract}
The madrasa head strategy is an important factor in determining the success of enhancing the religious culture of madrasas. The purpose of this research is to describe the strategy the head the Muslim teacher from the planning, implementation, supervision and obstacles in building religious culture. To achieve this goal, this study uses a qualitative approach with descriptive methods. Date collection techniques are done through Observation, Interview and Documentation Study. Data analysis procedures are Data Reduction, Data, and Verification. While the research subjects were the Head of Madrasah, Deputy Head of Madrasah, and Teacher. The results showed that: (1) Madrasa head strategy in developing religious culture (2) Obstacles faced by madrasa head in building religious culture in madrasa, teacher conditions in madrasas but still constrained by educators, lack of experts, while the environmental conditions of pupils also affect students which is just developing, whereas the institution itself has maximized extracurricular learning and other needs, so that the development of religious culture in the superior tsanawiyah madrasas is hikmatul amanah.
\end{abstract}

Keywords: Religius Culture, Head Masater Strategy, Student

https:

How to Cite Tajudin, A., \& Aprilianto, A. (2020). Strategi Kepala Madrasah.dalam Membangun Budaya Religius Peserta Didik. Munaddhomah: Jurnal Manajemen Pendidikan Islam, 1(2) 101-110.

\section{PENDAHULUAN}

Pendidikan merupakan salah satu pilar yang penting untuk meningkatkan kualitas sumber daya manusia. Pendidikan yang bermutu merupakan harapan setiap masyarakat..suatu negara. Pengalaman menunjukkan bahwa modal kehidupan dalam setiap perubahan zaman adalah pendidikan(I. Abdullah \& Safarina, 2015; Arifin, 2016). Pendidikan merupakan kunci utama bagi bangsa untuk menyiapkan masa depan yang lebih baik. Oleh karena itu, pendidikan dan semua elemen yang terkait didalamnya harus diberdayakan ke arah pencapaian tujuan penciptaan sumber daya manusia (SDM) semaksimal mungkin sehingga berkualitas(Haromain, 2014; Rosidi, 2018).

Undang-Undang Negara Republik Indonesia No. 20 tahun 2003 tentang Sistem Pendidikan Nasional Bab 2 Pasal 3 menyatakan bahwa "Pendidikan nasional berfungsi untuk mengembangkan kemampuan dan membentuk watak serta peradaban bangsa yang bermartabat dalam rangka mencerdaskan kehidupan bangsa, bertujuan untuk berkembangnya potensi peserta didik agar menjadi manusia yang beriman dan bertakwa kepada Tuhan Yang Maha Esa, berakhlak mulia, sehat, berilmu, cakap, kreatif, mandiri, dan menjadi warga negara yang demokratis serta bertanggung jawab.(Barmawi \& Arifin, 2016)" 
Fungsi dan tujuan pendidikan berdasarkan Undang- undang no 20 tahun 2003, ada dua hal penting yang harus diwujudkan lembaga pendidikan, yaitu; mengembangkan kemampuan dan membentuk watak. Pengembangan kemampuan berkaitan dengan head, sedangkan mengembangkan watak kaitanya dengan heart. Outcome pengembangan kemampuan merujuk pada kualitas akademik, sedangkan outcome dari membentuk watak adalah terwujudnya lulusan yang khusnul khuluk (Habibah, 2015; Kristiawan, 2016).

Pergeseran nilai-nilai dan norma pada saat ini semakin jauh dari apa yang diajarkan Islam, disebabkan karena adanya budaya-budaya barat yang masuk di Indonesia. Organisasi pendidikan dalam membentuk dan mengelola budaya Islam tidak terlepas dari strategi kepemimpinan kepala madrasah dalam mengorganisasikan seluruh elemen Madrasah yang ada(M. Abdullah, 2019; M. L. Abdullah \& Syahri, 2019a; Warti'ah, 2020). Organisasi dapat berhasil secara efektif dan efesien ditentukan oleh keahlian dari seorang pemimpin. Organisasi dapat lebih berhasil dari oraganisasi lain dikarenakan dipengaruhi oleh pimpinannya. Kepala madrasah sebagai pemimpin dan pengolah budaya religius, kepala madrasah salah satu dari suri tauladan yang ada dilembaga, kepala madrasah juga memiliki tanggung jawab untuk meningkatkan kualitas sumber daya manusia (Fatoni, 2017).

Kepala madrasah juga dituntut untuk mewujudkan suasana islami dalam madrasahnya, dengan cara menguasai beberapa kompentensi seperti: kepala madrasah sebagai edukator, menejerial, kewirausahaan, supervisor, menciptakan iklim kerja, dan layanan bimbingan konseling (Fauzi, 2017; Krisbiyanto, 2019; Ridwan, 2018). Penciptaan budaya religius berarti menciptakan suasana keagamaan. Dalam suasana dampaknya memberikan perkembangan hidup yang dijiwai oleh ajaran islam dan nilai-nilai religius yang dalam hidup sehari-hari serta ketrampilan dimasyarakat madrasah. Keberhasilan tujuan-tujuan tersebut tidak lepas dari peran kepala madrasah yang mempuyai wewenang dalam mengorganisasikan, mengarahkan, dan menselaraskan sumber daya pendidikan yang tersedia. kepemimpinan kepala madrasah menjadi salah satu faktor pendorong untuk mewujudkan Visi, Misi, tujuan serta sarana yang melalui program madrasah yang dilaksanakan secara terencana(Dahlan et al., 2017; Harmanto, 2014; Suradi, 2018).

Dalam hal ini kepala medrasah merupakan personal sekolah yang bertanggung jawab penuh dalam menyelenggarakan samua kegiatan pendidikan di sekolah yang dipimpinya. Kepala madrasah tidak hanya bertangguang jawab atas kelancaran jalanya kegiatan pendidikan secara teknis akademik saja, akan tetapi, keadaan lingkungan sekolah dengan kondisi dan situasi serta hubungan dengan masyarakat sekitar yang merupakan tanggung jawab demi meningkatkan kualitas pendidikan.

Kepala madrasah merupakan unsur vital bagi efektivitas lembaga pendidikan. Kepala madrasah yang baik akan bersikap dinamis untuk menyiapkan berbagai program pendidikan, "keberhasilan madrasah adalah keberhasilan kepala madrasah, kepala madrasah yang berhasil apabila memahami keadaan sekolah sebagai organisasi yang kompleks, serta mampu melakukan peranan dan bertanggung jawab untuk pemimpin”.

Lembaga Pendidikan merupakan tempat dan ladang dalam menanamkan karakter kepada siswa. Dalam penanaman karakter kita sebagai pemimpin dan masyarakat sekolah berperan penting dalam memberikan suri tauladan yang baik kepada siswa. Dalam hal ini kita perlu pembisaan untuk menciptakan kebiasaan yang positif dalam memebangun budaya religius di lembaga tersebut. Semisal guru di saat mengajar di dalam kelas, guru bukan hanya mentransfer ilmu pengetahuan akan tetapi memberikan nilai-nilai positif kepada peserta didik agar peserta didik memiliki kesadaran dalam melakukan perbuatan baik.

Di era globalisasi saat ini, pergeseran nilai-nilai, dan norma-norma Islam semakin jauh dari koridornya disebabkan karena adanya budaya-budaya barat yang masuk di indonesia. Keberhasilan organisasi pendidikan dalam membentuk dan mengelola budaya Islami tidak terlepas dari peran kepemimpinan Kepala Madrasah dalam mengorganisasi seluruh elemen sekolah yang ada. Oleh 
karena itu kepala madrasah yang memimpin organisasi pendidikan di lembaga sekolah tersebut memiliki peran yang sangat besar terhadap terciptanya budaya religius.

Dengan kata lain organisasi dapat berhasil secara efektif dan efisien ditentukan oleh ke ahlian dari seorang pemimpin. Sebuah organisasi dapat lebih berhasil dari pada organisasi lain dikarekan dipengaruhi oleh pemimpinya. Kepala Madrasah sebagai pemimpin dan sebagai pengelolah budaya religius memiliki tanggung jawab besar terhadap seluruh aspek pendidikan mulai dari proses belajar mengajar di kelas hingga mengorganisir satuan pendidikan. Oleh karena itu sebagai kepala madrasah harus memiliki kompetensi leadership dan kepemimpinan.

Membangun budaya religius di madrasah ini dilakukan dengan tiga cara : ajakan, pengamalan, dan pembiasaan(Almu'tasim, 2016). Budaya madrasah dibangun tentu memiliki sebuah tujuan tersendiri yaitu membantu dalam membina peserta didik. Dalam membina peserta didik untuk berproses menjadi dewasa dan budi pekerti yang baik tentunya dengan membangun budaya religius di dalam madrasah tersebut.

Pelaksanaan pendidikan madrasah tidak terlepas dari nilai-nilai, norma, keyakinan, perilaku, dan budaya religius. Budaya tersebut ketika diterapkan di madrasah akan berdampak kuat bagi prestasi lembaga. Membangun budaya religius dilembaga pendidikan, perlu adanya kerja sama dari seluruh elemen dalam lembaga, mulai dari kepala Madrasah sebagai leader, guru, staf, dan Peserta Didik. Seluruh masyarakat madrasah sangat menentukan keberhasilan dalam membangun budaya religius, karena budaya tersebut yang menjalankan adalah seluruh masyarakat madrasah (M. L. Abdullah \& Syahri, 2019b).

Strategi merupakan pola..umum rentetan kegiatan yang harus dilakukan untuk mencapai tujuan tertenntu. Kepala Madrasah sebagai seorang pimpinan di suatu lembaga pendidikan perlu mempunyai strategi tertentu untuk mengembangkan motivasi pendidik dan tenaga kependidikan di lingkungan kerjanya. Kepala Madrasah dilukiskan sebagai orang yang memiliki harapan tinggi bagi para staf dan para peserta didik. Sebagai kepala Madrasah dituntut untuk mampu melakukan sebuah perubahan dan terobosan guna peningkatan mutu dan kualitas Madrasah (Asmiyati, 2018; Danim, 2009).

Berdasarkan hasil survey awal yang dilakukan oleh peneliti, strategi yang digunakan oleh kepala madrasah dalam membentuk budaya religus yang akan diaplikasikan kepada peserta didik sesuai dengan visi misi dan tujuan yang ingin dicapai oleh lembaga madrasah. Madrasah Tsanawiyah Unggulan Hikmatul Amanah mempunyai usaha dalam membentuk budaya religius salah satu usaha dari strategi kepala madrasah dalam membangun budaya religius di Madrasah Tsanawiyah Unggulan Hikmatul Amanah,

Membiasakan peserta didik dalam kesehariannya sebelum melakukan aktifitas pembelajaran di kelas, seperti membaca surah yasin dilanjutkan dengan istighosah, sholat berjamaah di Aula ketika istirahat, progam menghafal qur'an dan menerapkan Senyum, Salam, Sapa, sopan dan santun (lima S) kepada sesamanya dan bersikap terhadap guru/ pendidiknya dan pengamalan yasin, istighosah yang sudah disebutkan di atas tadi terangkum dalam buku "dalilu annajah" yang artinya petunjuk keberhasilan, buku saku yang langsung disusun oleh pengasuh Pondok Pesantren Amanatul Ummah Prof Dr. KH. Asep Saifuddin Chalim, MA. Kenyataan yang ada di lapangan, setelah peneliti melakukan pra observasi langsung, yang peneliti temukan tidak mencerminkan apa yang disebutkan di atas tadi, yaitu kurang mengamalkan apa yang diharapkan dari kepala madrasah dan tujuan yang diharapkan madrasah, seperti sopan dan santun masyarakat madrasah, sholat berjemaah yang hanya dilakukan sebagian peserta didik, tidak membaca istighosah, kurangnya pengamalan yang terdapat pada kandungan al Qur'an "makaarimul akhlaaq" kesempurnaan akhlak.

Berdasarkan latar belakang di atas, begitu pentingnya membangun karakter dalam pencapaian keberhasilan pendidikan, menjadi dasar ketertarikan peneliti untuk melakukan 
penelitian dengan judul "Strategi Kepala Madrasah dalam Membangun Budaya Religius pada Peserta Didik di Madrasah Tsanawiyah Unggulan Hikmatul Amanah"

\section{METODE PENELITIAN}

Jenis penelitian yang digunakan yaitu jenis penelitian kualitatif dengan menggunakan pendekatan deskriptif. Informasi yang diperoleh dari informan digunakan sebagaimana adanya. Menurut Bog dan Taylor yang dikutip oleh Lexy Moleong mengatakan bahwa penelitian kualitatif adalah penelitian yang menghasilkan data deskriptif yang berupa kata-kata baik secara lisan maupun tertulis dari informan dan pelaku yang diamati.

Lokasi.penelitian.adalah.tempat yang digunakan oleh peneliti untuk melakukanpenelitian. Dalam.penilitian ini lokasi yang dijadikan tempat penelitian yaitu lembaga pendidikan Madrasah Tsanawiayah Unggulan Hikmatul Amanah BendunganJati, Pacet-Mojokerto. Madrasah Tsanawiayah Unggulan Hikmatul Amanah Bendungan Jati, Pacet, Mojokerto merupakan salah satu lembaga yang bergabung dengan salah satu yayasan Pondok Pesantren terbesar dan terbaik di Pacet Mojokerto yaitu Pondok Pesantren Amanatul Ummah.

Sebuah yayasan yang mengkolaborasikan pola pesantren dan umum merupakan yayasan yang patut diberikan nilai lebih oleh pemerintah karena tidak semua yayasan mampu untuk melakukan hal yang sama. Yayasan tersebut juga menjadi salah satu pusat perhatian masyarakat setempat sebagai bahan pertimbangan pendidikan yang sangat layak untuk generasi muda dimana Madrasah Tsanawiayah Unggulan Hikmatul Amanah Bendungan Jati, Pacet, Mojokerto merupakan salah satu lembaga yang terdapat didalamnya. Hal tersebut menjadi acuan sehingga peneliti memilih lokasi tersebut untuk dijadikan lokasi penelitian.

Subjek penelitian dalam penelitian ini menggunakan tekhnik purposive dimana pengambilan subjek penelitian didasarkan atas makna dan tujuan penelitian (Creswell, 2012; Lexy J, 2011; Suharsimi, 2016). Adapun subjek penelitiannya adalah kepala madrasah, guru, dan peserta didik Madrasah Tsanawiayah Unggulan Hikmatul Amanah BendunganJati, Pacet-Mojokerto.

Ada beberapa cara teknik pengumpulan informasi diantara yang banyak dipakai adalah: Observasi, Wawancara dan Dokumentasi. Pengamatan langsungadalah pengumpulan data berdasarkan pengamatan langsung, terhadap.kondisi lingkungan objek penelitian yang mendukung kegiatan penelitian, sehingga dapat gambaran yang jelas terhadap objek penelitian tersebut. Teknik observasi ini digunakan untuk mengamati dan mengetahui dari Strategi Kepala Madrasah Tsanawiyah Unggulan Hikmatul Amanah dalam Membangun Budaya Religius.

Wawancara.adalah proses memperoleh data untuk tujuan penelitian dengan cara tanya.jawab,sambil bertatap muka antara interviw dan responden dengan menggunakan.alat yang dinamakan panduan wawancara. Dokumentasi adalah catatan peristiwa yang sudah berlalu. Dokumentasi biasanya berbentuk tulisan, gambar, atau karya-karya menumental dari seseorang. Biasanya dokumentasi yang berbentuk tulisan, misalkan catatan harian, sejarah kehidupan, cerita biografi, peraturan dan kebijakan. Dokumentasi yang berbentuk gambar misalnya foto, gambar dan lain-lain(Sugiyono, 2008).

\section{HASIL DAN PEMBAHASAN}

\section{Strategi Kepala.Madrasah Tsnawiyah dalam Membangun Budaya Religius di Hikmatul Amanah}

Pendidikan..merupakan halyang sangat penting dalam menciptakan mengembangkan kemampuan dan membentuk watak dan karekter anak bangsa serta membangun peradaban bangsa yang bermartabat dalam rangka mencerdaskan kehidupan bangsa. Hal ini terus diupayakan seiring dengan tujuan untuk berkembangnya potensi peserta didik agar menjadi manusia yang bertaqwa 
dan beriman kepada Tuhan Yang Maha Esa, berakhlak mulia, mandiri dan bertanggung jawab. Kepala madrasah dalam hal ini memiliki perang yang sangat penting dalam menjalankan aktivitas setiap kegiatan pendidikan dan memimpin proses penyelenggaraan pendidikan di madrasah terutama membangun budaya religius yang ada di dalam lingkungan madrasah. Strategi kepala madrasah dalam membangun budaya religius di madrasah merupaka salah satu faktor yang sangat penting melalui optimalisasi peran kepala madrasah.

\section{Kepala Madrasah Sebagai Pendidik}

Sebagai kepala Madrasah Tsanawiyah Unggulan Hikmatul Amanah memiliki tanggung jawab dalam mengemban amanah sebagai pendidik. Dari hasil wawancara peneliti dengan Bapak Muhammad Albarra selaku kepala madrasah di Madrasah Tsanawiyah Unggulan Hikmatul Amanah mengemukakan bahwa:

"saya harus menjadi contoh terlebih kepada guru-guru dan siswa dan seluruh elemen yang ada di lingkungan madrasah sebelum Ia memerintahkan dan mengajak. Seperti contoh sholat berjamaah di madrasah, yang pertama kepala madrasah lakukan yaitu terlebih dahulu mengambil wudhu kemudian mengajak peserta didik lain untuk melaksanakan sholat berjamaah. Ia melakukan contoh ini tidak lain yaitu timbul rasa empati dari guru-guru untuk melakukan hal yang sama."

Kewajiban sosial, hukum dan moral harus dimiliki oleh kepala madrasah dalam menjalankan perannya sebagai pendidik. Kepala madrasah harus menjadi contoh teladan yang dapat digugu dan ditiru oleh peserta didik dalam melakukan aktivitas di lingkungan madrasah. Sebagai kepala madrasah memprioritaskan peserta didik adalah hal yang sangat penting dalam memberikan pengajaran yang baik secara sosial, hukum, dan moral berperilaku yang dapat di pertanggungjawabkan. Hal ini didukung berdasarkan observasi peneliti lingkungan, peneliti menemukan dari Strategi kepala madrasah sebagai pendidik yaitu dengan memberikan pendidikan formal dan non formal.

\section{Kepala Madrasah Sebagai Pengelola}

Proses pendidikan tidak lepas dari kegiatan merencanakan, mengorganisasikan,..melaksanakan,..dan..memimpin..serta..mengendalikan usaha para anggota organisasi dan mendayagunakan seluruh sumber-sumber daya organisasi dalam rangka mencapai tujuan yang telah ditentukan. Dikatakan sebuah proses, karena manajer dengan mendayagunakan bermacam kegiatan yang saling berkaitan untuk mencapai tujuan.

Religius: Pembinaan religius pada peserta didik sangat penting untuk dilakukan, karenanya perlu mendapat perhatian yang serius oleh pihak madrasah, terutama kepala madrasah sebagai pemegang kepemimpinan madrasah. Hal tersebut juga dinyatakan oleh bapak Muhammad Zumar selaku guru akidah akhlak Madrasah Tsanawiyah Unggulan Hikmatul Amanah.

"bercermin pada kondisi saat ini, kemajuan IPTEK dapat saja memberikan dampak positif maupun negatif pada peserta didik. Peserta didik yang tidak selektif dalam memilih dan memilah informsi dapat saja terjerumus pada hal-hal yang tidak diinginkan. Religius dapat menjadi benteng bagi peserta didik dalam menjalani kehidupan di tengah masyarakat. Pembinaan karakter religius pada dasarnya bukan hanya tanggung jawab pihak madrasah, melainkan tanggung jawab bersama oleh segenap stake holder madrasah. Semua harus berperan aktif dalam membina religius peserta didik".

Dalam implementasinya, pembinaan religius ini identik/memiliki hubungan yang erat dengan kegiatan-kegiatan keagamaan yang diselenggarakan oleh madrasah. Karena pada hakikatnya agama merupakan sumber dasar dari religius tersebut yang dikemas dengan sebaik mungkin, sehingga dapat memberikan pengaruh positif pada kepribadian peserta didik.

\section{Pembacaan Dalilu An Najah (Istighosah)}


Sebagaimana yang telah dijelaskan pada pembahasan terdahulu, bahwasanya pembacaan Dalil An Najah ini dilakukan setiap hari sebelum kegiatan belajar mengajar dimulai. Peserta didik sudah wajib berada di lingkungan madrasah sebelum pukul 06:45 WIB. Adapun rentetan kegiatan yang dilaksanakan, yakni: pembacaan Q.S Yasin yang dilakukan secara bersama-sama oleh peserta didik dengan dipandu oleh pengurus dari OPTSAHA (nama organisasi kesiswaan Madrasah Tsanawiyah Unggulan Hikmatul Amanah) hingga selesai, kemudian dilanjutkan dengan pembacaan do'a. Pembacaan Dalil An Najah dilakukan setiap hari sebelum melakukan aktivitas belajar mengajar. Ini dilakukan ketika apel pagi pada pukul 06:45 WIB, oleh karena itu peserta didik diwajibkan berada di lingkungan madrasah sebelum pukul 06:45 WIB. Adapun kegitan yang dilakukan di awal apel pagi yaitu: pembacaan Q.S Yasin, kemudian dilanjutkan dengan pembacaan Dalil An Najah/Istighosah. Pembacaan ini dilakukan bersama-sama yang di pandu oleh salah satu pengurus OSIS (Organisasi Siswa Intra Sekolah) hingga selesai, kemudian ditutup dengan pembacaan do'a. Hal ini diperkuat oleh Hasil observasi dan wawancara peneliti dengan Ibu Masroha seperti di bawah ini.

"salah satu strategi yang dilakukan oleh Kepala Madrasah yaitu membuat programprogram yang menjadikan lingkungan madrasah menjadi lingkungan yang bernuansa religius di antaranya yaitu ketika waktu apel pagi, dimulai dengan pembacaan Dalil An najjah. Disetiap apel pagi pembacaan Dalil An najjah dilakukan dengan tujuan untuk bermunajat kepada Allah/berdoa kepada Allah. Istighosah merupakan salah satu zikir yang sering dikumandangkan disetiap apel pagi, tak lain adalah zikir pagi. zikir adalah mengigat Allah. Siswa dibiasakan dengan berzikir sebelum masuk dalam kelas agar mereka terbiasa berzikir dan senantiasa selalu mengigat Allah"

Dalil An Najah merupakan dzikir yang dikumandangkan di setiap apel pagi. Pembacaan Dalil An Najah dengan tujuan agar peserta didik terbiasa membaca ayat-ayat Al-Quran dan senantiasa selalu ingat kepada Allah, sehingga selalu mengalir nilai-nilai kebaikan dalam diri setiap peserta didik yang melekat pada kepribadiannya. Pembacaan Dalil An Najah merupakan salah satu program yang dibuat oleh kepala madrasah dalam membangun budaya religius di lingkungan madrasah.

\section{Sholat Dzuhur dan Jum'at berjamaah di Aula Madrasah}

Sholat merupakan kewajiban yang harus didirikan oleh seorang muslim dalam setiap waktu yang telah ditentukan. Sholat juga merupakan salah satu rukun Islam yang ke dua, maka dari itu di wajibkan bagi seorang yang beriman kepada Allah untuk mendirikan sholat lima waktu dalam sehari. Sholat dzuhur dan jum'at berjama'ah adalah bagian dari program kepala madrasah dalam membangun budaya religius. Dari hasil wawancara peneliti dengan Ibu Masroha bahwa.

"menciptakan budaya religius di Madrasah Tsanawiyah Unggulan Hikmatul Amanah melalui beberapa program di antaranya yaitu kegiatan sholat dzuhur dan jum'at jama'ah. Kemudian anak-anak ditugaskan sebagai bilal dengan tujuan agar siswa terbiasa dan terlatih sehingga, ketika berada di masyarakat siswa bisa menjadi bilal. Setelah beberapa minggu siswa yang tadi menjadi bilal di sekolah langsung di tugaskan di masjid-masjid terdekat sekitar sekolah"

Program ini dibuat tidak lain karena salah satu bentuk Strategi dari kepala madrasah yang ingin menjadikan lingkungan madrasah menjadi lingkungan yang memiliki budaya religius.

Ekstrakurikuler

\section{Al-banjari}

Al-Banjari berasal dari dua suku kata yaitu "band" dan "jari". Adapun pengertian dari "band" itu sendiri adalah "group", sedangkan kata "jari" memiliki arti memaikan alat musik mengunakan jari tangan. Dapat kita artikan Al-Banjari adalah alat musik yang dimainkan oleh beberapa orang yang mengikuti irama lagu yang di lantunkan. Banjari terkenal dengan lantunan 
musik yang beriramakan syair-syair yang mengandung pujian dan sanjungan kepada baginda Nabi Muhammad SAW.

Banjari merupakan salah satu program yang dibuat untuk membantu peserta didik dalam menyalurkan bakat yang ada dalam diri mereka. Hal ini merupakan wadah untuk menjadikan peserta didik dapat mengembangkan bakat mereka seni, maka bakat yang mereka miliki dapat tersalurkan sesui dengan tuntunan dan ajaran Islam. Pertanyataan ini diperkuat oleh peneliti melalui wawancara dengan Ibu Masroha.

"Banjari, program ini menjadi salah satu bentuk upaya dalam membangun budaya religius. Dengan adanya tempat bagi peserta didik dalam mengembangkan bakat mereka di bidang seni maka bakat yang mereka miliki dapat tersalurkan dengan baik sesui dengan tuntunan dan ajaran agam. Jika hal ini terus dilakukan, maka peserta didik akan senang bersholawat, selalu mengingat dan cinta kepada Rosulullah"

Selain sebagai wadah dan tempat penyaluran bakat kesenian, Banjari juga memiliki fungsi sebagai wadah dalam membangun dan menumbuhkan kecintaan peserta didik kepada baginda Rosulullah SAW. Banjari juga selalu ditampilkan di setiap acara hari kebesaran islam seperti maulid nabi, isra'miraj, dan acara lainya, dilain kesempatan peserta yang sudah mahir dan bisa dalam memaikan banjari akan mengisi acara-acara yang ada di masyaratkat bahkan ketika ada lomba festival banjari sering diikut sertakan oleh guru pembimbingnya.

\section{Tahfidz}

Program tahfidz adalah suatu program yang dibuat untuk membiasakan peserta didik membaca dan menghafalkan Al-Qur'an. Tahfidz merupakan kegiatan yang di identikan dengan menghafal Al-Qur'an. Kegiatan ini diperuntukan untuk menanamkan nilai-nilai yang terkandung dalam Al-Qur'an kepada peserta didik. Budaya Madrasah

Dari hasil wawancara peneliti Madrasah Tsanawiyah Unggulan Hikmatul Amanah, menyatakan bahwa: "meskipun program 5S (salam, senyum, sapa, sopan, dan santun) ini belum diwajibkan di Madrasah Tsanawiyah Unggulan Hikmatul Amanah, akan tetapi sebagian besar peserta didik sudah melakukan hal tersebut" Dari hasil observasi yang dilakukan oleh peneliti, terlihat bahwa adanya relevansi fakta di lapangan. Peneliti mendapati bahwa beberapa peserta didik ketika bertemu dengan gurunya selalu mengucapkan salam, cium tangan, dan bertutur kata yang lembut.

\section{Faktor Penghambat Kepala Madrasah Dalam Membangun Budaya Religius Di Madrasah Tsanawiyah Unggulan Hikmatul Amanah.}

Pada umumnya kita telah mengetahui bahwa tidak ada lembaga yang sempurna atau telah baik seluruh sistem dan proses penyelenggaraan pendidikan. Tentunya faktor yang dihadapi proses dan penyelenggaraan pendidikan di tiap lembaga pendidikan memiliki kekurangan dan kendalakendala yang tentu dalam proses penyelenggaraan pendidikan itu sendiri. Hal ini seiring berjalannnya waktu tentu berbagai macam kekurangan dan kendala-kendala pasti berbeda-beda, apalagi seiring bergantinya masa dan zaman. Di Madrasah Tsanawiyah Unggulan Hikmatul Amanah memiliki beberapa kendala-kendala dalam proses penyelenggaraan pendidikan dalam membangun budaya religius.

Dalam pelaksanaan sebuah kebijakan ataupun sebuah program tidak luput dari hambatanhambatan dan masalah yang dihadapi. Hambatan cenderung sifatnya negatif karena memperlambat sebuah proses dalam pelaksanaan kegiatan atau program yang sedang dikerjakan.

Hambatan Internal

Dari hasil wawancara peneliti dengan wakil kepala Madrsah Tsanawiyah Unggulan Hikmatul Amanah, yang menyatakan bahwa: "Keterbatasan komunikasi antara madrasah dengan 
wali peserta didik menjadikan upaya peserta didik berjalan kurang efektif. Program-program yang dicetuskan madrasah berkenaan dengan peserta didik seringkali tidak tersampaikan dengan baik pada wali peserta didik yang berbeda terhadap keputusan madrasah. Meskipun ada agenda pertemuan dengan wali peserta didik, namun tidak semua dari mereka dapat hadir ke madrasah karena kesibukan dan jarak yang jauh"

Kurangnya Tenaga Pendidik

Khusus pada eksrakurikuler Tahfidz, kekurangan tenaga pendidik menjadikan kegiatan ini tidak berjalan dalam..waktu yang..cukup lama. Dari hasil wawancara yang dilakukan peneliti dengan kepala madrasah, bapak Muhammad Al-Barraa menyatakan bahwa:

"Karena belum adanya tenaga pengajar yang siap untuk membimbing peserta didik, maka ekstrakurikuler Tahfidz terpaksa harus diberhentikan untuk sementara waktu. Namun untuk mengendalikan situasi tersebut, pihak madrasah mengupayakan kerja sama dengan beberapa mahasiswa yang dianggap memiliki kemampuan untuk membimbing peserta didik pada ekstrakurikuler Tahfidz ini."

Kurangnya Minat dari Peserta Didik

Dalam wawancara peneliti dengan guru akidah akhlak Madrasah Tsanawiyah Unggulan Hikmatul Amanah, bapak Muhammad Zumar menyatakan,

"Diantara kendala yang dihadapi dengan peserta didik saat ini adalah kurangnya minat dan kesadaran peserta didik untuk mau melakukan hal-hal yang baik dan bermanfaat, karna kita semua tau bahwa peserta didik yang baru lulus sd, masih membawa sikap bermainnya, masih bertahap untuk mengarahkannya."

Melalui observasi lapangan, hal serupa juga peneliti temukan. Peserta didik lebih memilih berbincang dan berkumpul dengan teman-temanya untuk sesuatu yang kurang bermanfaat, dibandingkan dengan pergi ke perpustakaan untuk membaca buku atau ke mushollah untuk sholat dhuha dan membaca Al-Qur'an atau melakukan kegiatan yang bermanfaat lainya.

Hambatan Ekternal

Pengaruh Lingkungan.

Berdasarkan hasil wawancara Ibu Masroha menyatakan bahwa:

“Lingkungan memberikan pengaruh luar biasa pada pembentukan peserta didik. Peserta didik yang berada pada lingkungan yang baik, memiliki kecenderungan untuk menjadi baik. Begitupun sebaliknya, peserta didik yang berada pada lingkungan yang kurang baik, maka akan berpengaruh tidak baik pula pada pembentukan. Sekalipun madrasah menerapkan model penddikan full day scholl, tetap saja pendidik memiliki keterbatasan kemampuan untuk melakukan kontrol pada siswa. Peranan orang tua yang reletif masih kurang membuat pembinaan peserta didik menjadi lebih sulit."

Hal serupa juga dinyatakan oleh kepala madrasah bapak Muhammad Al-Barraa, yang menyatakan bahwa:

"Model pendidikan full day scholl cenderung membentuk stigma negatif pada orang tua peserta didik. Orang tua peserta didik cenderung pasrah dan menyerahkan persoalan pendidikan anaknya pada pihak madrasah. Hal itu menjadikan pihak madrasah dalam membangun budaya religius peserta didik tidak maksimal

\section{KESIMPULAN}

Setelah melakukan penelitian dan pengamatan yang diperoleh tentang Strategi yang digunakan kepala madrasah dalam membangun budaya religius peserta didik di madrasah tsanawiyah unggulan hikmatul amanah, maka diperoleh kesimpulan sebagai berikut: Enam nilai 
yang dituntut oleh kepala madrasah untuk menjadi acuan dan dapat dikembangkan oleh peserta didik yaitu karakter religius, disiplin, tanggung jawab, jujur, mandiri dan peduli. Terdapat beberapa faktor yang menjadi penghambat dalam upaya membangun budaya religius peserta didik di madrasah tsanawiyah hikmatul amanah yaitu: (a) Hambatan Internal, yaitu keterbatasan dalam bentuk komunikasi oleh pihak madrasah dengan orang tua siswa. (b) Hambatan Eksternal, yaitu pengaruh lingkungan serta kurangnya peran keluarga terhadap keseharian anak sehingga mereka dapat terbius dengan keadaan lingkungan yang semakin hari semakin tak terkendali

\section{REKOMENDASI}

Berdasarkan kesimpulan yang telah dikemukakan di atas, maka saran yang dapat peneliti kemukakan sehubungan dengan hasil penelitian ini ialah:

Kepala Sekolah, agar kiranya selalu memantau jalannya proses belajar mengajar dan ikut memeriksa guru-guru tentang pelaksanaan berbagai strategi dalam proses pembelajaran sehingga pelanjaran berlangsung secara maksimal. Kepada Semua guru bidang studi diharapkan untuk terus memberikan semangat dan selalu meneraokan adanya perencanaan pembeljaran di Sekolah. Serta gunakan strategi yang menarik dalam proses belajar mengajar agar dapat meningkatkan semangat anak. Kepada siswa agar lebih termotivasi dalam proses pembelajaran sehingga mencapai tujuan dan cita-cita yang diinginkan dan tidak terpengaruh dengan lingkungan sekitar yang tidak semakin terkontrol

\section{REFERENSI}

Abdullah, I., \& Safarina. (2015). Etika Pendidikan, Keluarga, Sekolah dan Masyarakat (Cet. 2). PT Raja Grafindo.

Abdullah, M. (2019). School Culture to Serve Performance of Madrasah in Indonesia. QIJIS (Qudus International Journal of Islamic Studies), $7(1), \quad 71$. https://doi.org/10.21043/qiijis.v7i1.4809

Abdullah, M. L., \& Syahri, A. (2019a). Model of Religious Culture Education and Humanity. Nadwa, 12(2), 331-344. https://doi.org/10.21580/nw.2018.12.2.2756

Abdullah, M. L., \& Syahri, A. (2019b). Model of Religious Culture Education and Humanity. Nadwa, 12(2), 331-344. https://doi.org/10.21580/nw.2018.12.2.2756

Almu'tasim, A. (2016). Penciptaan Budaya Religius Perguruan Tinggi Islam (berkaca Nilai Religius Uin Maulana Malik Ibrahim Malang). J-PAI: Jurnal Pendidikan Agama Islam, 3(1), Article 1. https://doi.org/10.18860/jpai.v3i1.3994

Arifin, S. (2016). Islamic religious education and radicalism in Indonesia: Strategy of deradicalization through strengthening the living values education. Indonesian Journal of Islam and Muslim Societies, 6(1), 93. https://doi.org/10.18326/ijims.v6i1.93-126

Asmiyati, A. (2018). Model Kepemimpinan Kepala Madrasah dalam Meningkatkan Mutu Sumber Daya di Madrasah Ibtidaiyah Ma'arif Giriliyo I Wukirsari Imogiri Bantul. Jurnal Pendidikean Madrasah, 3(1), 41-54. https://doi.org/10.14421/jpm.2018.31-04

Barmawi, \& Arifin, M. (2016). Strategi dan kebijakan pembelajaran pendidikan karakter | Perpustakaan Universitas Sanata Dharma. Ar-Ruz Media. http://library.usd.ac.id/web/index.php?pilih=search\&p=1\&q=0000137573\&go=Detail

Creswell, J. W. (2012). Educational research: Planning, conducting, and evaluating quantitative and qualitative research (4th ed). Pearson.

Dahlan, D., Hasim, D., \& Hamdan, H. (2017). Pengaruh Manajemen Sumber Daya Manusia dan Budaya Organisasi Terhadap Kualitas Pelayanan Pada Kantor Kecamatan Tamalate Kota Makassar. Jurnal Ad'ministrare, 4(2), 69-75.

Danim, S. (2009). Manajemen dan kepemimpinan transformasional kekepalasekolaban: Visi dan strategi sukses era teknologi, situasi krisis, dan internasionalisasi pendidikan. Rineka Cipta. 
Fatoni, M. (2017). Peran Kepala Madrasah Dalam Meningkatkan Mutu Guru Di Mts Nurul Falah Talok Kresek Kabupaten Tangerang. Tarbawi: Jurnal Keilmuan Manajemen Pendidikan, 3(02), 168-182. https://doi.org/10.32678/tarbawi.v3i02.1787

Fauzi, A. (2017). Kepemimpinan Kepala Madrasah Dalam Mengembangkan Lembaga Pendidikan Islam. Nidhomul Haq: Jurnal Manajemen Pendidikan Islam, 2(2), 42-53. http://ejournal.ikhac.ac.id/index.php/nidhomulhaq/article/view/31

Habibah, S. (2015). Akhlak Dan Etika Dalam Islam. Jurnal Pesona Dasar, 1(4).

Harmanto, H. (2014). Pendidikan Antikorupsi melalui Budaya Sekolah Berbasis Nilai-nilai Keislaman. ISLAMICA: Jumal Studi Keislaman, 7(1), 100-122. https://doi.org/10.15642/islamica.2012.7.1.100-122

Haromain, H. (2014). Manajemen Pengembangan Sumber Daya Manusia (SDM) Pondok Pesantren. Jurnal Pendidikan Humaniora, 1(2), 136-149. http://journal.um.ac.id/index.php/jph/article/view/4047

Krisbiyanto, A. (2019). Efektifitas Kepemimpinan Kepala Madrasah terhadap Mutu Pendidikan MTsN 2 Mojokerto. Nidhomul Haq: Jurnal Manajemen Pendidikan Islam, 4(1), 52-69. https://doi.org/10.31538/ndh.v4i1.182

Kristiawan, M. (2016). Telaah Revolusi Mental dan Pendidikan Karakter dalam Pembentukkan Sumber Daya Manusia Indonesia Yang Pandai dan Berakhlak Mulia. Ta'dib, 18(1), 13-25.

Lexy J, M. (2011). Metodologi penelitian Kualitatif (29th ed.). Rosdakarya.

Ridwan, M. (2018). Konsep Tarbiyah, Ta'lim Dan Ta'dib Dalam Al-Qur'an. Naz̧bruna: Jurnal Pendidikan Islam, 1(1), 35-57. https://doi.org/10.31538/nzh.v1i1.41

Rosidi, I. (2018). Pengembangan SDM Dalam Pembentukan Karakter Santri di Lembaga Pengabdian pada Masyarakat (LPM) Pondok Pesantren Wahid Hasyim Yogyakarta. TA'LIM: Jurnal Studi Pendidikan Islam, 1(1), 106-120. http://ejurnal.unisda.ac.id/index.php/talim/article/view/637

Sugiyono. (2008). Metode penelitian pendidikan: (Pendekatan kuantitatif, kualitatif dan R \& D). Alfabeta.

Suharsimi, A. (2016). Metode Penelitian Pendidikan dan Pengembangan (5th ed.). Kencana.

Suradi, A. (2018). Penanaman Religiusitas Keislaman Berorientasi pada Pendidikan Multikultural di Sekolah. Jurnal Pendidikan Agama Islam (Journal of Islamic Education Studies), 6(1), 25-43. https://doi.org/10.15642/jpai.2018.6.1.25-43

Warti'ah, W. (2020). The Implementation of Madrasa Culture in Building Students' Character. Naz̧hruna: Jurnal Pendidikan Islam, 3(2), 247-259. https://doi.org/10.31538/nzh.v3i2.583 